\title{
Making new friends: Social concepts of study abroad
}

\section{Huang, Hsiao-Ching}

Department of Applied Foreign Languages, Lunghwa University of Science and Technology, Taiwan (amylikecat@yahoo.com.tw)

Chen, Shun-Der

Department of Library and Information Science, Fu Jen Catholic University, Taiwan (ryanchen@lins.fju.edu.tw)

\section{Ching, Gregory S.}

Graduate Institute of Educational Leadership and Development, Fu Jen Catholic University, Taiwan (gregory_ching@yahoo.com; 094478@mail.fju.edu.tw)

Received: 14 March 2014

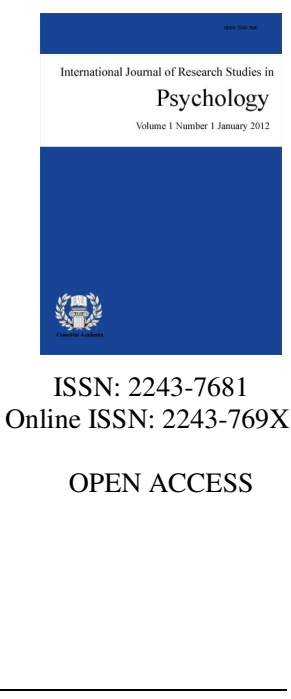

\section{Abstract}

For the past few years, Asian universities have been trying to position themselves as a venue for study abroad opportunities. This is also quite true in Taiwan, wherein universities are exerting much effort in the recruitment of international students. Within the paradigm of internationalization, having international students in Taiwan is a way to promote communication, understanding, and friendship between other countries around the world. Moreover, it is hypothesized that successful internationalization is built upon the friendships that are form between student exchanges. In addition, with the current increased emphasis in student exchanges with mainland China, it would be quite important to determine the various concepts on friendship within these students. Therefore, the current study seeks to analyze the different insights between the Chinese and local Taiwan students' concepts on friendship. Using a mixed-method paradigm, 6 groups of volunteer students enrolled in a technical and vocational university in Taiwan participated in a series of focus group discussions. Afterwards, a survey was designed from the focus group interview results. The survey was then administered to 200 volunteer mainland Chinese and local Taiwan students. Statistical results show that there are both similarities and differences within the concepts on friendship. Local students are eager to make friends with their international peers, while majority of them thought primarily of the opportunity to understand a new culture. In addition, survey results also show that the highest factor is the social results; wherein the students' goal is to expand their world view and gain interpersonal relationship.

Keywords: study abroad; social norms; intercultural friendship; mixed-method study; focus groups interview 


\section{Making new friends: Social concepts of study abroad}

\section{Introduction}

In a recent Asian conference on study abroad, an agreement was reached that Asian higher education institutions should start to place strong efforts in emphasizing their role as an international student destination (Baker, 2011, p. 11). Study abroad or more technically known as international student mobility has already become a global education industry (Kwiek, 2005). Since the late 70s, higher education institutions have already started to recruit international students as a way of increasing their financial resources (Dore, 1976). After 30 years, within a more recent paradigm, Knight $(2003,2004)$ noted that study abroad is a strategy wherein higher education seeks to integrate international, intercultural, and global dimensions into the undergraduate education. With the current dilemma of decreasing number of university students in Taiwan, combining the two concepts seems to be a quite viable solution. Therefore, having a large number of international students in the school campus will not only boost an institutions' internationalization atmosphere, but also increases its revenue.

As the Taiwan government emphasizes more in attracting international students. Higher education institutions in Taiwan are undergoing drastic changes, whether in their admission policies or with their curriculum contents (Chin \& Ching, 2009; Ching \& Chin, 2012). Within the paradigm of internationalization, having international students in Taiwan is indeed a way in promoting an avenue for understanding, and friendship between other countries around the world (Lewis, Ching, \& Su, 2013; Roberts \& Ching, 2011). Hence, fruitful study abroad experiences shall ultimately aid in the process of international student recruitment (Ching, Lien, \& Chao, 2014). More importantly, international students population can also acts as a cultural ambassadors; if positively played, will eventually bring to their home countries the improved understanding of Taiwan as a host country for international studies. In essence, successful intercultural friendship provides opportunities that can help create cultural bridges across geographical boundaries for Taiwan.

For the past three years, Taiwan has started to accept incoming students from across the strait from mainland China (Zhao, 2010). To date, the numbers of mainland Chinese students coming to Taiwan either for degree seeking or study abroad program have been gradually increasing. With the current goal of increasing the movement of students within the Asian region (Hawkins, Mok, \& Neubauer, 2012; Knight, 2013), understanding how students communicate and how friendship occurs would be of prime importance. In addition, the notion of mainland Chinese students not having the problem of language as compared to other non-Mandarin Chinese speakers within Asia or other international students. Therefore, it is assumed that mainland Chinese students should have lesser difficulties in adjusting to the Taiwan educational system. Discussions regarding this issue are currently beyond the scope of this paper. However, a follow up study is already underway. In sum, the lesser language barrier would seem to pave the way for better and easier communication, understanding, and friendship between the mainland Chinese and local Taiwan students.

Within the paradigm of internationalization, it is hypothesized that successful internationalization is built upon the friendships that are form between student exchanges. Therefore, the current study shall seek to analyze the different insights between the mainland Chinese and local Taiwan students' concepts on friendship. In response, this mixed-method study utilizes the focus-group interview method to compare the different insights between the students' concepts on friendship. Afterwards, the focus group interview results are then compiled into a survey to further gather and collect data from the students. Initial research questions are as follows:

$>\quad$ What are the students' concepts, goals, and/or objectives of friendship?

$>\quad$ What are the factors that influence the students' concepts on friendship?

$>\quad$ What are the different perceptions on the social network structure in Taiwan? 


\subsection{Nature of friendship}

In general, we define friendship as the state of being friends. Wright (1984) mentioned that friendship can be differentiate from the other types of relationships by looking into the nature of the interaction. When people meet someone new and become friends, people treat each other as a person with meaning and not just an occupant within a certain role (Bell, 1981). In the west, friendship varies from short-term superficial ones to long-term committed ones (Matthews, 1986). However, within an Asian point of view, typically in a Chinese setting, friendship lasts for a very long time ( $\mathrm{Li}, 2010)$. As with many studies have assumed their own definition of friendship, few have tackled how participants are attached to the word friends (Matthews, 1986). The concept on friendship is quite complex and the underlying motivations are varied and largely unexplored.

Several studies have shown that friendship occurs due to three major reasons, namely: proximity, similarity, and self-disclosure $(\mathrm{Li}, 2010)$. This could be explained that the opportunities to meet someone, finding something of familiar interest, and the willingness to share are quite important ingredients in making friends. It is also said that the initial contact is crucial (Berscheid \& Walster, 1991; Ting-Toomey, 1981), giving grounds to the notion of first impression last. While, people are easy to get attracted or get along with others who are similar to themselves (Osbeck \& Moghaddam, 1997), in a sense, having something in common to talk about is key making a good conversation. Lastly, self-disclosure; which is the sharing of information with others, has often shown that the desire to opened up and share something personal develops closeness between people (Collins \& Miller, 1994).

It is also said that the concept of friendship changes with age, gender, region of origin, and cultural background (Adams, Blieszner, \& De Vries, 2000). Hence, intercultural friendship can be said to be characterized by individuals' culture differences. More importantly, such difference in perspectives are potential causes of conflict, uncertainty, and frustrations (Bennett, 1986). In a study, Zhang and Merolla (2007) mentioned that intercultural friendship within a school setting is quite dependent with personal contact. Furthermore, language and communications skills are also important in establishing and maintaining intercultural friendship (Lee, 2006). In sum, various factors are present in both Western and Asian intercultural friendship situations, such as the individualism-collectivism, masculinity-femininity, and language-communication (Li, 2010). Hence, it would be quite important to determine and categorized such factors, in order, to provide a well situated environment for both international and local students to get acquainted and get along.

In a study by Trice and Yoo (2007), wherein they surveyed 497 international students studying in the US; their results show that the extent to which students are able to establish informal social support networks may influence the amount of time that they have plan to remain in the host country to work after completing their degree. This study suggests that the idea of local social support networks could actually help diminish the international students' stress, but also promote a sense of acceptance and belongingness. Furthermore, Gargano (2009) mentioned that by focusing on social, cultural, academic, and support networks, it is possible to acknowledge the constraints and power relations between friends. In addition, a recent study suggests that by establishing a study abroad friendly campus environment, students are able to adapt easily and develops intercultural competencies (Chen \& Ching, 2012). In essence, with the right type and amount of supports provided to international students' transition and adapting to the studying in Taiwan would become easier.

Within a different spectrum, in a mixed method study regarding international students in Australia, Neri and Ville (2006) mentioned that a negative impact might be produced with poor social networks. Lastly, in a more recent study, Lewis (2013) and her colleagues noted that international students actually have their own social networks. More importantly, at the center of these networks are key individuals that assume the role of connectors that links other social networks together. Accordingly, the better the acculturation international students have, the stronger the social network will be. In sum, as the international students (including mainland Chinese students) population grows in Taiwan, it is hope that their study experiences in Taiwan would bring to them fruitful experiences and long lasting friendship. Therefore understanding the concepts on friendship would 
Huang, H.-C., Chen, S.-D., \& Ching, G. S.

pave the way in creating activities geared towards better cultural understanding.

\section{Methodology}

\subsection{Research design}

This study employs a descriptive research paradigm. Best (1970) describes that descriptive research is much concerned with the conditions that exist and the practices that prevail or attributes that are ongoing within a certain setting. With this in mind, the current descriptive study shall focus on depicting the existing scenarios regarding the concepts of friendship among the mainland Chinese and local Taiwan students.

\subsection{Study participants and research process}

To understand the different concepts of friendship, a series of focus group interviews is accomplished with various volunteer student groups. Focus group interviews is a process of interaction among individuals with a common point of interest, wherein a moderator tries to gather the needed information (Stewart \& Shamdasani, 1990). An invitation was send out to the mainland Chinese students and local student population within a science and technology university in Northern Taiwan during the middle of the spring of 2013. A total of 6 focus group sessions were accomplished. With the first 3 sessions for the Mainland Chinese students, while the remaining 3 sessions for the local Taiwanese students. This is deliberately design to gain the contrasting point of views from the students. A consent form was distributed informing the objective of the discussions. Students are also informed that they can freely leave the session if they are uncomfortable with the topic of discussions. Each of the session lasts approximately 45 minutes.

After the focus group discussion interviews, data analysis and interpretation of the results was accomplished. All of the interviews were recorded with prior permission from the participants. Stenhouse's (1988) categorization style of case data was used to analyzed the data gathered. Lastly, besides the themes generated from the focus group interview results, a survey questionnaire was also design based on the emerging themes. The survey questionnaire was subjected to content validity with the help of four faculties with previous experiences in study abroad researches.

The survey was distributed to 200 volunteer students (100 local Taiwan students and 100 mainland Chinese students). As an incentive in completing the survey, each student was given a complementary pen as a token of appreciation. Table 1 shows that the survey participants consists of 78 or $39 \%$ male students, while there are around 122 or $61 \%$ female students. With regards to the students' year of study, no freshman students were surveyed, while the remaining participants consisting of 36 or $18 \%$ 2nd year students, 68 or $34 \%$ third year students, and 96 or $48 \%$ fourth year students. It is noted that most international students who comes to Taiwan are mostly junior $\left(3^{\text {rd }}\right.$ year $)$ or senior $\left(4^{\text {th }}\right.$ year, graduating) students.

\section{Table 1}

Survey participants demographics $(N=200)$

\begin{tabular}{lccc}
\hline & Variables & $n$ & $\%$ \\
\hline \multirow{2}{*}{$\begin{array}{l}\text { Male } \\
\text { Female }\end{array}$} & Gender & 78 & $39 \%$ \\
& & 122 & $61 \%$ \\
2nd year & Year level & & \\
3rd year & & 36 & $18 \%$ \\
4th year & & 68 & $34 \%$ \\
\hline
\end{tabular}




\subsection{Research tools}

The study uses a survey questionnaire developed from the results of the focus group sessions. Besides the standard demographical backgrounds of the participants, the survey is divided into six sections, namely: social confidence; describes the students' confidence in making friends, social condition; describes the situations wherein the students interact with each other, social aim; describe the purpose of making friends or acquaintance; social results; are the perceived benefits of having foreign friends; and social satisfaction; as the perceived satisfaction of the interaction between foreign friends. The reliability of the survey was computed with a Cronbach alpha of 0.92, which is considered to be quite reliable (Cohen, Manion, \& Morrison, 2007).

\section{Results and discussions}

The current primarily aims of the current study is to answer these three questions, namely: 1) What are the students' concepts, goals, and/or objectives of friendship? 2) What are the factors that influence the students' concepts on friendship? and 3) What are the different perceptions on the social network structure in Taiwan? Discussions shall be separated into the three questions.

\subsection{The students' concepts, goals, and/or objectives of friendship}

With regards to the students' objectives of friendship, Table 2 summarizes the results of the focus group interviews. Note that groups 1 to 3 are the mainland Chinese students, while the remaining groups 4 to 6 are the local students. Results show that all of the students who attend the focus group sessions has international friends (foreign national friends); this is inclusive of students from other countries such as the US, Vietnam, Thailand, and Malaysia. When ask about making friends with mainland Chinese students (for the local students) and Taiwanese students (for the Mainland Chinese students), results show that most Chinese students would immediately make friends with the local Taiwan students. However, the local students seem hesitant at first, but will eventually agree to become friends with the mainland Chinese students. When also asked regarding the students concern with language barriers, most (almost all) students stated that there are no obstacle. This shows that whether the students speak a very different language, students (both mainland Chinese and local Taiwan students) tries to use a common language, which is English to communicate. As for the Taiwan and mainland Chinese students, there exists no problem, since both of them uses Mandarin Chinese to communicate.

With regards to the reasons for making an acquaintance, students of both groups have varied opinions. However, one distinct result which is the notion of knowing and/or experiencing a new culture first-hand is found in both groups. This result is persistent with all other studies with regards to study abroad experiences (Roberts \& Ching, 2011). When the students are asked regarding the method for communication between friends, still the most number of the answers is using some kind of social network software, such as Facebook. In essence, students felt that the experience of having a new friend, specially an international student is beneficial for their study experience.

\subsection{The factors that influence the students' concepts on friendship}

As for the factors regarding the students' concepts on friendship, results are collected from the survey which was administered to 200 volunteer students. As mentioned before, besides the demographical backgrounds of the participants, the survey is divided into six sections, namely: social confidence; describes the students' confidence in making friends, social condition; describes the situations wherein the students interact with each other, social aim; describe the purpose of making friends or acquaintance; social results; are the perceived benefits of having foreign friends; and social satisfaction; as the perceived satisfaction of the interaction between foreign friends.

Table 3 shows that the highest factor is the social results with an overall mean of 4.37. Similar to previous 
Huang, H.-C., Chen, S.-D., \& Ching, G. S.

notions, students all mentioned the importance of learning about a new culture (mean score of 4.30), the concept of having a world view (mean score of 4.44), and expanding interpersonal relationship (mean score of 4.38) as the highest items in the survey. The lowest factor noted is the social condition with an overall mean 3.04, this shows that some students still are in the initial phase of their friendship, they are just beginning to know the culture of their peers. Although the students' motivations are high, upon engaging with their foreign national friends, they seem to become more reluctant than they are supposed to be.

\section{Table 2}

Focus group interview results for $R Q 1$

\begin{tabular}{|c|c|c|c|c|c|c|}
\hline Questions/Groups & 1 & 2 & 3 & 4 & 5 & 6 \\
\hline Do you have foreign national friends? (Yes/No) & * & $*$ & $*$ & $*$ & $*$ & $*$ \\
\hline $\begin{array}{l}\text { Do you take the initiative in making acquaintances with the foreign } \\
\text { national students (or Taiwan Students)? (Yes/No) }\end{array}$ & $*$ & $*$ & $*$ & - & - & $*$ \\
\hline $\begin{array}{l}\text { Whether language is your obstacle between you and the foreign } \\
\text { national students? (Yes/No) }\end{array}$ & - & - & - & - & - & - \\
\hline
\end{tabular}

What are the reasons that you want to make acquaintances with the foreign national students (or Taiwan Students)?

\begin{tabular}{|c|c|c|c|c|c|c|}
\hline Make friends & $*$ & $*$ & - & - & * & $*$ \\
\hline Ask for help & $*$ & $*$ & - & - & - & - \\
\hline Expand relationship & - & - & - & $*$ & $*$ & $*$ \\
\hline Learn different culture & $*$ & $*$ & $*$ & $*$ & $*$ & $*$ \\
\hline
\end{tabular}

\begin{tabular}{|c|c|c|c|c|c|c|}
\hline \multicolumn{7}{|c|}{ 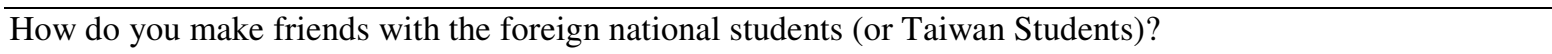 } \\
\hline Phone calls & - & - & - & - & - & - \\
\hline Exchange Social network ID & $*$ & $*$ & $*$ & $*$ & $*$ & $*$ \\
\hline Go outing & - & - & - & $*$ & - & - \\
\hline Others & $*$ & - & - & - & - & - \\
\hline
\end{tabular}

Note: ${ }^{*}$ signifies yes, - = no

Phone calls

Others

Table 3

Survey results $(N=200)$

\begin{tabular}{|c|c|c|c|c|c|c|}
\hline Factors/Items & $0 \%$ & $25 \%$ & $50 \%$ & $75 \%$ & $100 \%$ & Mean \\
\hline Social confidence & & & & & & 3.56 \\
\hline 1. I am a quiet and introvert person in class?* & 7 & 68 & 88 & 18 & 19 & 3.14 \\
\hline 2. I feel difficult to talking to lots of people?* & 8 & 100 & 60 & 26 & 6 & 3.19 \\
\hline $\begin{array}{l}\text { 3. It is hard for me to do discussion with foreign } \\
\text { students?* }\end{array}$ & 50 & 103 & 36 & 6 & 5 & 3.93 \\
\hline 4. It is hard for me to make friends in college?* & 68 & 98 & 18 & 12 & 4 & 3.99 \\
\hline $\begin{array}{l}\text { 5. It is hard for me to make acquaintances with the } \\
\text { foreign national students?* }\end{array}$ & 76 & 60 & 37 & 17 & 10 & 3.81 \\
\hline 6. I have confidence with my language ability? & 6 & 6 & 34 & 59 & 95 & 4.16 \\
\hline $\begin{array}{l}\text { 7. I feel I can ask for some information with foreign } \\
\text { friends easily in class? }\end{array}$ & 23 & 66 & 57 & 34 & 20 & 2.81 \\
\hline $\begin{array}{l}\text { 8. I feel to make acquaintances with the foreign } \\
\text { national students is easy? }\end{array}$ & 26 & 74 & 33 & 43 & 24 & 2.83 \\
\hline $\begin{array}{l}\text { 9. If I saw a foreign friend which I want to know, I } \\
\text { will actively make friends with him/ her? }\end{array}$ & 10 & 84 & 54 & 33 & 19 & 2.84 \\
\hline 10. I am willing to make a team with foreign friends? & 0 & 17 & 45 & 56 & 82 & 4.02 \\
\hline 11. I am willing to study with foreign friends? & 0 & 18 & 47 & 62 & 73 & 3.95 \\
\hline $\begin{array}{l}\text { 12. I am willing to sit with foreign friends during the } \\
\text { class? }\end{array}$ & 0 & 16 & 39 & 62 & 83 & 4.06 \\
\hline
\end{tabular}

Note. *Items coded in reverse. Overall mean scores for each factor are shaded in bold. 
Making new friends: Social concepts of study abroad

Table 3 ... continued

\begin{tabular}{|c|c|c|c|c|c|c|}
\hline Factors/Items & $0 \%$ & $25 \%$ & $50 \%$ & $75 \%$ & $100 \%$ & Mean \\
\hline Social condition & & & & & & 3.04 \\
\hline 1. I can talk about my difficulty with foreign friends? & 16 & 27 & 76 & 43 & 38 & 3.30 \\
\hline $\begin{array}{l}\text { 2. Language is an obstacle for me to make friends } \\
\text { with foreign friends?* }\end{array}$ & 75 & 62 & 39 & 10 & 14 & 3.91 \\
\hline $\begin{array}{l}\text { 3. Cultural difference is an obstacle between me and } \\
\text { foreign friends?* }\end{array}$ & 34 & 28 & 98 & 26 & 14 & 3.09 \\
\hline 4. I have the common topic with foreign friends? & 17 & 53 & 109 & 10 & 11 & 2.73 \\
\hline $\begin{array}{l}\text { 5. I can get emotional support and help form foreign } \\
\text { friends? }\end{array}$ & 13 & 58 & 97 & 20 & 12 & 2.80 \\
\hline $\begin{array}{l}\text { 6. Foreign friends who surround me are willing to } \\
\text { help me? }\end{array}$ & 6 & 68 & 103 & 11 & 12 & 2.78 \\
\hline 7. I usually chat with foreign friends? & 5 & 69 & 93 & 21 & 12 & 2.83 \\
\hline 8. I usually study with foreign friends? & 13 & 58 & 107 & 12 & 10 & 2.74 \\
\hline 9. I usually go out with foreign friends? & 7 & 29 & 98 & 46 & 20 & 3.22 \\
\hline Social aim & & & & & & 4.28 \\
\hline $\begin{array}{l}\text { 1. I hope to learn different culture from foreign } \\
\text { friends? }\end{array}$ & 0 & 9 & 20 & 87 & 84 & 4.23 \\
\hline 2. I hope to gain different view of world? & 0 & 7 & 21 & 86 & 86 & 4.26 \\
\hline 3. I hope to expand interpersonal relationship thought & 0 & 6 & 19 & 82 & 93 & 4.31 \\
\hline
\end{tabular}

make acquaintances with the foreign national students?

4. Make acquaintances with the foreign national $\quad \begin{array}{llllll}0 & 8 & 13 & 89 & 90 & 4.31\end{array}$ students make me feel proud?

\section{Social results}

1. I can learn different culture from foreign friends?

2. I can learn different view of world from foreign

friends?

3. I can expand interpersonal relationship?

\section{Social satisfaction}

1. I feel foreign friends are easy to get along with?

2. Foreign friends make me feel relax?

3. I feel foreign friends are worthy trust?

4. I am willing to keep contact with foreign friends afterward?

5. I feel it is worth making acquaintances with the foreign national students?

6. I like the feeling that I get along with foreign friends?

7. I feel foreign friends are enthusiastic?

Note. *Items coded in reverse. Overall mean scores for each factor are shaded in bold.

\subsection{The different perceptions on the social network structure in Taiwan}

As for the perceived social network structure, students are asked specifically if they would sit beside an international student or not. They are also asked regarding their communication frequency between each other. Results show that most of the students talked to each other during school days. They share and talk about everything, besides the school work, the major topic of discussions is day to day life, shopping issues, and tourism tips, which are quite similar in some ways to the findings of another study focusing on the situational changes that happen during study abroad (Ching et al., 2014).

Although the initial notion of being seated with an international student is to make new friends, some students revealed that they would also use the opportunity to ask their seatmates when they encounter some difficulty during classes. More importantly, most international students (including mainland Chinese students) tend to be the focus of their classroom teachers. During the focus group sessions, two local Taiwan students mentioned that they somewhat felt that teachers would give special considerations to the international students. 
Huang, H.-C., Chen, S.-D., \& Ching, G. S.

Discussions regarding this notion are beyond the topic of the current study. It is hoped that future studies would be able to consider the different types and levels of interaction not only between international and local students, but to also include student and faculty interactions.

\section{Table 4}

Focus group interview results $-R Q 3$

\begin{tabular}{|c|c|c|c|c|c|c|}
\hline Items/Groups & 1 & 2 & 3 & 4 & 5 & 6 \\
\hline \multicolumn{7}{|l|}{ How often do you chat with the foreign national students (or Taiwan Students)? } \\
\hline Once a week & - & - & - & - & - & - \\
\hline Twice a week & - & - & - & - & $*$ & * \\
\hline Three times a week & - & $*$ & - & - & - & - \\
\hline Almost everyday & - & - & - & - & - & - \\
\hline Everyday & $*$ & - & $*$ & $*$ & - & - \\
\hline $\begin{array}{l}\text { Do you sit with the foreign national students (or Taiwan Students) } \\
\text { when in class? (Yes/No) }\end{array}$ & $*$ & - & - & $*$ & - & $*$ \\
\hline \multicolumn{7}{|c|}{ Why do you want to sit with the foreign national students (or Taiwan Students) during the class? } \\
\hline Make friends & $*$ & $*$ & - & $*$ & $*$ & $*$ \\
\hline Ask for help & $*$ & $*$ & $*$ & - & - & - \\
\hline There are no other place to sit (by chance) & - & - & $*$ & - & - & - \\
\hline
\end{tabular}

Note: $*$ signifies yes, - = no

\section{Conclusion}

The major findings of the study are as follows. First of all, according to the results of the interview regarding the reasons why students choose in order to make acquaintances with the foreign national students (or Taiwan Students); the most possible reasons are making friends and learn a different (new) culture. Meanwhile, one of the student mentioned that the reason that he apply to come to Taiwan as an exchange student is due to his desire of know the Taiwan culture. Both of these answers are quite in line with the goal of study abroad and culture learning. During their stay in Taiwan, many of the students claimed that they realize the true concept on friendship; which is to gain new friends. In addition, most of the local students still suggests that the possibility of continuous communication even if the foreign classmates/friends have gone back home. This goes to show that both the international exchange students and the local Taiwan students do not only make friends when they are in need of help; in fact, they are also willing to keep in contact when they go back to their country.

In a successful model of study abroad, re-establishment of support networks in the host country favors host nationals. This is actually one of the key points in having international students in Taiwan. Besides the myth of brain gain (Baruch, Budhwar, \& Khatri, 2007), it is perceived that students bring to their home countries the social network gains that they have accumulated during their study in Taiwan. With the hope that the friendship connection will last, such friendships might led to future partnership either in business or cultural exchange. The presumed returns would be immeasurable. Lastly, one of the international exchange students mentioned that friends are not only friends, the relationship they have will last for a long time if not forever. The concept and experience of friendship is unique to each individual. It is believed that when the experience is fruitful, this would translate into a beneficial factor for encouraging students to study in Taiwan. As the word of mouth advertisement is way much stronger and effective. To sum up, although the concepts on friendship are different to each person, what is the most important is to keep an open mind and everything should work out just fine.

Acknowledgement: This work is supported in part by the Taiwan Ministry of Science and Technology (MOST, formerly National Science Council, NSC) under grant numbers NSC 102-2815-C-262-008-H and NSC 102$2410-\mathrm{H}-262-012-\mathrm{SS} 2$. We are very grateful to the anonymous reviewers for the valuable comments and suggestions. 


\section{References}

Adams, R., Blieszner, R., \& De Vries, B. (2000). Definitions of friendship in the third age: Age, gender, and study location effects. Journal of Aging Studies, 14(1), 117-133. http://dx.doi.org/10.1016/S0890-4065(00)80019-5

Baker, A. (2011). Asia-Pacific to compete for international students. Retrieved from http://thepienews.com/analysis/asia-pacific-to-compete-for-international-students/

Baruch, Y., Budhwar, P. S., \& Khatri, N. (2007). Brain drain: Inclination to stay abroad after studies. Journal of World Business, 42(1), 99-112. http://dx.doi.org/10.1016/j.jwb.2006.11.004

Bell, R. R. (1981). Friendships of women and of men. Psychology of Women Quarterly, 5(3), 402-418. http://dx.doi.org/10.1111/j.1471-6402.1981.tb00582.x

Bennett, M. J. (1986). A developmental approach to training for intercultural sensitivity. International Journal of Intercultural Relations, 10(2), 179-196. http://dx.doi.org/10.1016/0147-1767(86)90005-2

Berscheid, E., \& Walster, E. (1991). Self-esteem and attraction. Journal of Personality and Social Psychology, 17(1), 84-91.

Best, J. W. (1970). Research in education. Englewood Cliffs, NJ: Prentice Hall.

Chen, Y.-L., \& Ching, G. S. (2012). A case study on the effects of campus climate to the cross-cultural norms of Taiwanese students. International Journal of Research Studies in Psychology, 1(1), 3-16. http://dx.doi.org/10.5861/ijrsp.2012.v1i1.4

Chin, M. C., \& Ching, G. S. (2009). Trends and indicators of Taiwan's higher education internationalization. The Asia-Pacific Education Researcher, 18(2), 185-203. http://dx.doi.org/10.3860/taper.v18i2.1322

Ching, G. S., \& Chin, M. C. (2012). Managing higher education institution internationalization: Contemporary efforts of a university in Taiwan. International Journal of Research Studies in Management, 1(1), 3-16. http://dx.doi.org/10.5861/ijrsm.2012.v1i1.9

Ching, G. S., Lien, W.-C., \& Chao, P.-C. (2014). Developing a scale to measure the situational changes in short-term study abroad programs. International Journal of Research Studies in Education, 3(5), 53-71. http://dx.doi.org/10.5861/ijrse.2014.771

Cohen, L., Manion, L., \& Morrison, K. (2007). Research methods in education. New York: Routledge.

Collins, N. L., \& Miller, L. C. (1994). Self-Disclosure and liking: A meta-analytic review. Psychological Bulletin, 116(3), 457-475. http://dx.doi.org/10.1037/0033-2909.116.3.457

Dore, R. P. (1976). The diploma disease. Berkeley: University of California Press.

Gargano, T. (2009). (Re)conceptualizing international student mobility: The potential of transnational social fields. Journal of Studies in International Education, 13(3), 331-346. http://dx.doi.org/10.1177/1028315308322060

Hawkins, J. N., Mok, K. H., \& Neubauer, D. E. (Eds.). (2012). Higher education regionalization in Asia Pacific: Implications for governance, citizenship and university transformation. New York: Palgrave Macmillan. http://dx.doi.org/10.1057/9781137311801

Knight, J. (2003). Internationalization of higher education practices and priorities: 2003 IAU survey report. Paris, France: International Association of Universities.

Knight, J. (2004). Internationalization remodeled: Definition, approaches, and rationales. Journal of Studies in International Education, 8(1), 5-31. http://dx.doi.org/10.1177/1028315303260832

Knight, J. (2013). A model for the regionalization of higher education: The role and contribution of tuning. Tuning Journal for Higher Education, 1, 105-125.

Kwiek, M. (2005). The university and the state in a global age: Renegotiating the traditional social contract? European Educational Research Journal, 4(4), 324-342. http://dx.doi.org/10.2304/eerj.2005.4.4.1

Lee, P.-W. (2006). Bridging cultures: Understanding the construction of relational identity in intercultural friendship. Journal of Intercultural Communication Research, 35(1), 3-22. http://dx.doi.org/10.1080/17475740600739156

Lewis, A., Ching, G. S., \& Su, Y. N. (2013). A case study on the international students' social adaptability in Taiwan: A qualitative study. International Journal of Research Studies in Psychology, 2(1), 13-24. http://dx.doi.org/10.5861/ijrsp.2012.161

Li, Z. F. (2010). Bridging the gap: Intercultural friendship between Chinese and Americans. Unpublished Masteral Thesis. Liberty University.

Matthews, S. H. (1986). Friendships through the life course: Oral biographies in old age (Vol. 161). Beverly Hills: Sage Publication.

Neri, F., \& Ville, S. (2006). The social capital experience of international students in Australia: The Wollongong experience [Electronic Version]. Economics Working Papers, from http://ideas.repec.org/p/uow/depec1/wp06-19.html 
Huang, H.-C., Chen, S.-D., \& Ching, G. S.

Osbeck, L. M., \& Moghaddam, F. M. (1997). Similarity and attraction among majority and minority groups in a multicultural context. International Journal of Intercultural Relations, 21, 113-123. http://dx.doi.org/10.1016/S0147-1767(96)00016-8

Roberts, A., \& Ching, G. S. (2011). Concepts, contributions, and challenges of the contemporary university community in Taiwan. In J. Palmer, A. Roberts, Y. H. Cho \& G. S. Ching (Eds.), The internationalization of East Asian higher education (pp. 41-62). New York: Palgrave Macmillan.

Stenhouse, L. (1988). Case study methods. In J. P. Keeves (Ed.), Educational research, methodology, and measurement: An international handbook. Sydney: Pergamon Press.

Stewart, D. W., \& Shamdasani, P. N. (1990). Focus groups - Theory and practice. Newbury Park, California: Sage Publications.

Ting-Toomey, S. (1981). Ethnic identity and close friendship in Chinese-American college students. International Journal of Intercultural Relations, 5(4), 383-406. http://dx.doi.org/10.1016/0147-1767(81)90049-3

Trice, A. G., \& Yoo, J. E. (2007). International graduate students' perceptions of their academic experience. Journal of Research in International Education, 6(1), 41-66. http://dx.doi.org/10.1177/1475240907074788

Wright, P. H. (1984). Self-referent motivation and the intrinsic quality of friendship. Journal of Social and Personal Relationships, 1(1), 115-130. http://dx.doi.org/10.1177/0265407584011007

Zhang, S. Y., \& Merolla, A. J. (2007). A group project on communication and intercultural friendship. Communication Teacher, 2(1), 16-20. http://dx.doi.org/10.1080/17404620701211535

Zhao, H. (2010). Taiwan-mainland economic cooperation framework agreement. Retrieved from http://www.eai.nus.edu.sg/BB549.pdf 